\title{
All The World Is A Stage: Global Governance, Human Resources and the 'Problem' of Smallness
}

\author{
Jack Corbett
}

State, Society and Governance in Melanesia

School of International, Political \& Strategic Studies

ANU College of Asia \& the Pacific

Australian National University

Canberra ACT 0200

AUSTRALIA

jack.corbett@anu.edu.au

Tel: +61 261258394

Fax: +61261255525

John Connell

School of Geosciences

The University of Sydney

Sydney NSW 2006

john.connell@sydney.edu.au

A slightly amended version of this paper is forthcoming in the journal The Pacific Review 


\begin{abstract}
Small Island States (SIS) in the Pacific are increasingly involved in international organisations, which have placed demands on national bureaucracies and political systems. Global governance offers development possibilities for small states but these have rarely been effectively realised. Skilled human resources are scarce in most SIS but technical demands on them have increased with the proliferation of global, regional and national organisations, and the increased technical complexity and sophistication of global negotiations. The ability of leaders of SIS to influence international affairs, has weakened over time as a new generation of leaders has taken over, with limited longevity, more rapid turnover, less experience of international organisations and more limited international and local support. The reduced influence of political leaders, greater pressures on the bureaucracy and inexperience in diplomacy have further weakened the ability of already disadvantaged SIS to achieve national development. As global and national governance has become more complex the frailties and vulnerability of SIS, notably in human resources, have been exposed. National sovereignty does not always equal control, and what might superficially appear to be equal access is constrained by the availability of technical expertise to the detriment of SIS.
\end{abstract}

Key Words: Pacific islands, International Organisations, Global Governance, Small Island States 
'Governments of small states will, despite their vulnerability, have to consider how they can become better informed - and therefore tougher' (Jacobs 1975: 141-2)

'There is a feeling of being insignificant out there: small and insignificant and the big countries were not taking us seriously. But when it came to voting I felt we were significant, even if you are a small country' (i-Kiribati politician)

\section{Introduction}

Small island states (SIS) in the Pacific are generally seen to occupy a precarious place in international affairs. Based on the relative ease with which many were absorbed within colonial empires, international relations scholars have traditionally defined this vulnerability in terms of weak military capacity (e.g. Rothstein 1966, Vital 1971). From this perspective, which sees the state-based order as anarchic, vulnerability is primarily understood in terms of small populations and land masses, inadequate strategic resources and weak defence capabilities. Similarly, despite many SIS gaining independence from the 1970s, they are still considered vulnerable by scholars from the market-liberal tradition who perceive their economic development being limited through a combination of now well-known factors: narrow resource bases (including human resources), remoteness, fragmentation, susceptibility to natural hazards (from cyclones to earthquakes), vulnerability to external economic shocks, excessive dependence on aid and imports, and fragile environments. The most remote SIS are particularly disadvantaged (Gibson 2007) and have remained dependent for some key services on such external institutions as universities and banks.

In contrast, global governance, defined here as the increased role of international organisations (IO) in regulating international affairs, as outlined by the United Nations (UN) Commission on 
Global Governance report (1995), ostensibly provides considerable new advantages for SIS in the international community; they are no longer sites where major powers waged armed conflict (MacQueen 1993, Warrington 1998, Wivel and Oest 2010). This commitment to peaceful intergovernmental relationships, where the actions of states are curtailed by a global 'civic ethic', recognises growing plurality in the arena of global governance (involving the increased influence of non-government organisations (NGOs), citizens' movements, multinational corporations, and global capital markets on international affairs) simultaneously contributing to a new complexity (Carlsson et al. 1995: 3). The advantage of this new arrangement for small states stems from a belief that:

The principles of sovereignty and non- intervention must be adapted in ways that recognize the need to balance the rights of states with the rights of people, and the interests of nations with the interests of the global neighbourhood. It is time also to think about self-determination in the emerging context of a global neighbourhood rather than the traditional context of a world of separate states (UN, 1995:337).

This argument has theoretical underpinnings. Keohane (1969:297) saw one of the major functions of IOs as allowing all states, including small ones, to shape the norms of international relationships through alliances with 'great powers'. The recent emphasis on inclusiveness should, in theory, provide greater scope for small states to affect the operation and outcomes of IOs as formally, relative to their population size, SIS have a stronger per capita bargaining position than larger states in IOs (Crocombe 2008: 379).

This paper explores how leaders of SIS see their representative capacity in IOs, including the benefits and costs of participation. Since Keohane (1969), the literature on small states in IOs 
either focuses on their relationships with larger states or 'great powers' (e.g. Stringer 2006; Van Fossen 2007) or the capacity of their domestic bureaucracies (Jacobs 1975, Murray 1985, Bray 1992, Schahczenski 1992, ADB 1995). We take a different approach. Drawing on in-depth interviews with island leaders, we add a new dimension to this discussion by focusing on how they experience the activities and practices of IOs. We examine how global governance can raise the profile of Pacific SIS, and rally support for their causes, but illustrate how the ability of SIS to steer policy directions is often limited by capacity constraints.

IOs are not blind to the challenges SIS face when representing themselves in the international arena - the World Trade Organisation (WTO) provides internships for Pacific Island civil servants whilst the Commonwealth Secretariat has set up an office to support SIS in Geneva but as global governance has become more complex the frailties and vulnerability of SIS, especially in human resources, have increasingly been exposed. Examining the reflections of leaders on how international relationships within IOs are negotiated thus suggests that sovereignty does not always equal control, and what might superficially appear to be equal access, or influence generated through alliances with great powers, is constrained by the availability of technical expertise to the detriment of the SIS involved. Consequently, the conventional view of small states exerting bargaining influence through alliances with large states is undermined by the new complexities of global governance and their limited capacity to negotiate effectively within and between these institutions. Increasingly, the administration of IOs matters (Xu and Weller, 2009), but while this broadens the focus away from 'great powers' potentially to the benefit of SIS like those in the Pacific, the sheer number of IOs, far beyond the focus of much of the international relations literature, and the demands of membership can overwhelm small states, undermining apparent benefits. 
The aim of this article is not to denigrate small states by casting them as powerless 'victims'. As the Kiribati politician quoted at the beginning of this article articulates (see also [omitted]), strategically adept Pacific SIS can derive benefits from IOs by leveraging aid, support from larger states like Russia, Taiwan and China (Stringer 2006; Van Fossen 2007), and by voting in blocs (like the ACP). There are also substantial benefits associated with being classified as 'small' and 'developing' by IOs: membership of the UN Small Island Developing States network, for example, or access to the Commonwealth Secretariat's Small States Office. We cannot provide an exhaustive account of how the international system benefits and constrains small states within one article, despite this being a necessary area for further research. Our objective is more modest and fundamental. By focusing on how SIS leaders experience the activities and practices that involve them in IOs (Table Two illustrates how extensive this involvement is), we show that despite the advantages that membership should and can bring, benefits often remain underutilised or even unrealised. We argue that SIS capacity is an important, if often overlooked, reason for this. We are therefore exploring barriers to SIS realising greater benefits from participation in IOs as experienced by their leaders.

The interview material presented here is derived from a substantial 2011-12 project exploring the life stories of 102 politicians from the 13 Pacific SIS (Table One). Central to these interviews were reflections on the relationship between politicians, and ministers in particular, and the bureaucratic machinery. The impact of this on representation in IOs emerged inductively from this process. The methodological aspects of this project have been detailed at length elsewhere ([omitted]) hence is not reproduced here. Following the conventions of interpretive research (Yanow and Schwartz-Shea, 2010), the sample was not representative in a quantitative sense, especially given the diversity of populations and parliament sizes across these countries, but 
sought to understand the breadth of experiences. The data is presented in the form of quotes or thick descriptions, rather than being coded and quantified, to demonstrate the range of perspectives rather than to assess the relative strength or otherwise of particular interpretations. In all cases they could have been substituted for several others. All quotes are from these interviews unless otherwise stated. Interviews have limitations; they can be a platform for selfjustification, perhaps more so for politicians, but they provide the most practical way of establishing how insiders interpret their roles within political institutions, and the more we conducted the more confidence we had in the emerging patterns (Xu and Weller, 2009: 17). This perspective is also of particular value given its absence from the existing literature.

\section{Who is Small and Why?}

Table 1: Political Entities in the Pacific Islands

Source: The information for this table is drawn from Connell (2013) and the Secretariat of the Pacific Community

Defining a small island state is fraught with contradictions. We specifically refer to the independent and self-governing Pacific countries in (Table One), which are conventionally divided into three sub-regions: Melanesia (Fiji, Solomon Islands, and Vanuatu), Polynesia (Cook Islands, Niue, Samoa, Tonga, and Tuvalu), and Micronesia (Federated States of Micronesia (FSM), Kiribati, Nauru, Marshall Islands, and Palau). Definitions of relative 'smallness' usually emphasise population, land area or economic size (Crowards 2002, Moisio 2011, Connell 2013). 
Here we see smallness as also derived from bureaucratic discourse which creates and sustains a narrative about size. Certainly, small states perceive themselves as quite different from larger states and believe they are disadvantaged as a result. Thus, in extremis, when the UN Decolonisation Committee encouraged Tokelau in 2002 to take on a greater degree of independence, its leader pointed out: 'We are so small; we are afraid of any move to the future in case we make a mistake' (quoted in Connell 2009a: 165). Similar concerns over national capacity have discouraged movement towards independence in other small Pacific territories (Amoamo 2013).

International institutions have a long history of engaging with the 'problem' of smallness (see Benedict 1967, Dommen and Hein 1985; Rapaport, Muteba and Therattil 1971). In the period between 1974 and 1994 twenty-one microstates, defined as those with populations less than 250,000 (Veenendaal 2013: 44), nine in the Pacific, became members of the UN. In 1992 the UN Conference on Environment and Development captured the unique challenges faced by Small Island Developing States in Agenda 21 (a non-binding, voluntarily implemented action plan of the UN with regard to sustainable development). Since then, multiple attempts have distinguished various groups of small states with relative disadvantage and vulnerability being the core distinctive themes (Connell 2013). In 2000 the World Bank also began to take a special interest in small states, eventually identifying 'a diverse group of some 40 sovereign countries with limited populations for which diseconomies of scale and resource constraints constitute inherent challenges' (World Bank 2012: ii). That group excluded Tuvalu and Nauru, neither being World Bank member states. 
Since independence, Pacific SIS have joined increasing numbers of IOs (Table Two). Very substantial participation in regional organisations, like the Pacific Islands Forum, South Pacific Regional Environment Program, the University of the South Pacific, the Forum Fisheries Agency, the South Pacific Tourism Organisation or the Pacific Island Development Program which in many ways consume more SIS resources than IOs ([omitted]) - is beyond the scope of this article. Membership of IOs raises a number of questions: why some Pacific countries have aggressively pursued membership whereas others have not, whether some IOs are easier for SIS to deal with than others and, most importantly, how ineffectual participation of SIS affects the function of IOs. For our purposes however, the sheer quantity and diversity of membership illustrates the extent to which SIS are absorbed into a global and regional international system.

Table 2: IO Membership of Pacific Island States

\section{Text}

Source: The information for this table is drawn from The World Factbooki. ACP: African, Caribbean and Pacific Group; ADB: Asian Development Bank; AOSIS: Alliance of Small Island States; C: The Commonwealth; CP: Colombo Plan; EITI: Extractive Industry Transparency Initiative; ESCAP: Economic and Social Commission for Asia and the Pacific; FAO: Food and Agriculture Organisation of the UN; G-77: Group of 77 at the UN, IAEA: International Atomic Energy Agency; IBRD: International Bank for Reconstruction and Development; ICAO: International Civil Aviation Organisation; ICRM: International Red Cross and Red Crescent Movement; IDA: International Development Association; IFAD: International Fund for Agricultural Development; IFC: International Finance Corporation; IFRCS: International Federation of Red Cross and Red Crescent Societies; IHO: International Hydrographic Organisation; ILO: International Labour Organisation; IMF: International Monetary Fund, IMO: International Maritime Organisation; Interpol: International Criminal Police Organisation; IOC: International Olympic Committee; ISO: International Organisation for Standardisation; ITSO: International Telecommunication Satellite Organisation; ITU: International Telecommunication Union; IMSO: International Mobile Satellite Organisation; ITUC (NGOs): International Trade Union Confederation; IPU: Inter-Parliamentary Union; MIGA: Multilateral Investment Guarantee Agency; NAM: Nonaligned Movement; OAS: Organisation of American States; OPCW: Organisation for the Prohibition of Chemical Weapons; OIF: International Organisation of La Francophonie; PCA: Permanent Court of Arbitration; Sparteca: South Pacific Regional Trade and Economic Cooperation Agreement; SPC: Secretariat of the Pacific Community; UN: United Nations; UNAMID: African Union-UN Mission in Darfur; UNCTAD: UN Conference on Trade and Development; UNESCO: UN Educational, Scientific, and Cultural Organisation; UNIDO: UN Industrial Development Organisation; UNMISS: United Nations Mission in the Republic of South Sudan; UNMIT: UN Integrated Mission in Timor-Leste; UNWTO: World Tourism Organization; UPU: Universal Postal Union; WCO: World Customs Organization; WFTU (NGOs): World Federation of Trade Unions; WHO: World Health Organisation; WIPO: World Intellectual Property Organisation; WMO: World Meteorological Organisation; WTO: World Trade Organisation. 
While these questions require further examination, we can infer that SIS are largely involved in the international arena in the belief that: there is something to be gained by participating; because they are encouraged to participate by an international community seeking to legitimate their decisions; and because the fate and future of SIS rests, at least partly, in other hands. Samoa, for example, is a member of 33 IOs (not including numerous regional organisations, sporting, religious and other social organisations), while Vanuatu is a member of 36: crude but impressive measures of institutional globalisation. The rationale for this strategy of participation was articulated by then Chair of the Pacific Islands Forum, Samoan Prime Minister Tuilaepa Sailele Malielegaoi, in March 2005:

Every time we join an international agreement or a grouping of nations - such as the [Pacific Islands] Forum or the United Nations or the Cotonou Agreement with the European Union - we agree to give up a little bit of our sovereignty not only for the common good but for our needs as a government and as a nation. We should never complain about losing sovereignty if we do it willingly in order to gain something in return.

This illustrates that while membership of IOs varies substantially between countries (Table Two) - and it is impossible to examine each instance in detail - SIS exercise some discretion over which IOs they join. Thus FSM, Palau and Samoa are members of the IPU yet other Pacific nations are not. That Tuvalu and Nauru have chosen not to join the World Bank indicates both some degree of choice and an implicit value judgment on the costs and benefits of membership. However, the recent experience of Tonga, Samoa and Vanuatu with WTO accession highlights that there is often substantial pressure on SIS to join some key organisations that may not provide any significant benefits but incur compliance costs ([omitted]; Gay 2005; Grynberg and 
Joy 2006; Wallis 2010). In several instances pressure has been placed on SIS by countries like Israel to join IOs, such as the International Atomic Energy Agency (IAEA), that offer no obvious advantages (ABC, 15 November 2013). Reflecting on why he rejected an application from a national senior bureaucrat to attend a meeting of IAEA, one Minister maintained:

We have a practice of signing up to anything, and then not being able to pay the dues so we have huge arrears to all of these organisations. It is idiots who just want to travel and get the allowance you know. It is an issue that the Ministry of Foreign Affairs has looked into. We have to rationalise our membership. I think we can gain a lot from our membership of international organisations but we have got to know what we want.

Where scholars have previously seen SIS vulnerability on the world stage as defined by their military and economic incapacity, weak bureaucratic capacity - defined here in Weberian terms - results in similar asymmetries within global governance, as Pacific SIS are unable to participate as effectively as larger states, even compared with more successful participation in IOs by SIS from elsewhere (e.g. Pace 2006). However, firstly, capacity is a broad term, but is employed here specifically to refer to skilled human resources (Norris 2012: 33-34). Secondly, it is beyond the scope of this article to apportion blame for this situation, the antecedents of which have a complex colonial and post-colonial history, alluded to below, which invariably reflect trends in the broader international political economy. However, again, our argument is more modest and fundamental: the sheer complexity of the new global governance regime makes it increasingly difficult for the leaders of SIS to negotiate with IOs due to asymmetries in the level of technical support at their disposal. Thirdly, as we have explored in detail elsewhere ([omitted]), countries like Fiji, the largest Pacific state considered here and with a particular 
colonial legacy, are advantaged relative to microstates like Nauru and Tuvalu. While intuitively a continuum, with microstates at one end and larger or wealthier small states at the other, implies difference, any break or tipping point is impossible to substantiate empirically. Fourthly, while nine Pacific SIS (Table One) are independent sovereign nations, five (the former American colonies of Palau, FSM and Marshall Islands, and the former New Zealand colonies of Niue and Cook Islands) are governed in free association with their former colonial power. This has an obvious impact on their engagement with IOs; the Crown, as represented by New Zealand, has a constitutional responsibility over Niue's external affairs whilst Palau supports the US in $96 \%$ of votes in the UN General Assembly, the most of any country, and FSM and Marshall Islands are not far behind. This further complicates the capacity of domestic bureaucracies to support their leaders in IOs, but the extent to which this matters more than other SIS is again difficult to substantiate.

While highlighting weak bureaucratic capacity in SIS is not new - numerous studies of bureaucracies in small states have long pointed to the considerable challenges in developing adequate national bureaucracies (Jacobs 1975, Murray 1985, Bray 1992, Schahczenski 1992, ADB 1995) - here we extend this argument to participation in IOs with specific reference to the reflections of Pacific leaders. In doing so we provide a deeper exploration of how bureaucratic capacity constraints impede SIS in IOs by looking specifically at the impact of: institutional legacy; migration and the 'brain drain'; shortage of technical knowledge; shrinking resources and public sector reforms; limited research capacity; and the relative high costs of diplomatic representation. We conclude by considering some of the solutions proposed by the international community and island leaders to this problem - good governance; regionalism; importing 
technical expertise; and targeted interaction - but find these initiatives do not substantially alter the status-quo.

\section{The Problem of Small Bureaucracies}

Despite their small size, SIS are expected to have a bureaucratic structure much like that of larger states since, at a different scale, the same functions are required. This has several effects. Statehood creates disproportionate costs, including environmental protection, infrastructure development, national defence and international representation, for functions hitherto undertaken by colonial authorities (Campling and Rosalie 2006), and explains the reluctance of some territories, like Tokelau, to take on these burdens. Costs are also a disincentive. Western Samoa (now Samoa) did not join the UN until 14 years after independence. Tuvalu and Kiribati waited more than twenty years and Nauru waited 31 years. More specifically, small states are more likely to require senior officials to act in multifunctional roles, including being responsible for departments that would be quite separate in larger states. Similarly, holding multiple portfolios is not uncommon in SIS where, due to the relative size of parliament, individuals often undertake overlapping roles. At independence, Cook Islands agreed to the establishment of a cabinet of five ministers despite the public service having around 20 departments who previously reported to the New Zealand governor (Wettenhall, 2001: 170). However, the then premier, Sir Albert Henry, found this situation untenable and by the early 1970s implemented a reform process that regrouped departments and increased the number of ministries. Yet the problem remained and is echoed across the region's smallest states (Niue's parliament has a constitutional cap of four ministers while until recently the constitution of Kiribati provides for 11 cabinet positions). 
In SIS, bureaucrats and politicians are neither specialised nor do they 'enjoy the luxury of concentrating on one responsibility or a specific cluster of concerns' (Farrugia 1993: 22). This can have advantages in domestic administration - a highly flexible workforce - but in an increasingly specialised global environment generalisation is a disadvantage. SIS face 'severe and permanent challenges' in accessing an adequate range and depth of technical skills to fulfil the basic functions that are required for such crucial issues as monitoring public expenditure and maintaining financial accountability (Haque et al 2012). Officials in small states lack the professional interchange, access to new knowledge and stimulus provided by professional associations and meetings and may 'live in a condition of professional loneliness' (Jacobs 1975: 141). Recently one of the authors received an email from a senior bureaucrat in Vanuatu requesting literature on monetary policy in developing countries; not only did this person have no domestic network of professionals with whom to discuss this but lacked access to back-up databases. Such key people may often be abroad for substantial time periods and be unavailable to manage and discuss national development. That was evident in Nauru, where five cabinet ministers hold multiple portfolios:

There was a regional meeting in Vanuatu where they were inviting the Minister for Health and the Minister of Education and so on. I said "Well - that means all of us should go."

In light of this historical legacy, catching up has been a continuous, incomplete process. At independence SIS were often left unprepared; Tuvalu had just two university graduates, and in one ministry only the minister and his secretary had more than primary education (McIntyre 2012), a gap described by this I-Kiribati politician: 
It is very intimidating, coming from a small [country]. At the big meetings, like the Commonwealth Heads of Government Meeting ... I observed the big leaders talking and performing and I must admit I regarded it as a learning thing for me. People like Lee [Kuan Yew] from Singapore, when they talk they are articulate and confident ... It also depends on your personality as well, because there are people who find it easy ... I found it uncomfortable in that sort of environment, as it were. I mean coming from the village background and the island situation, it was quite a new world so it is not easy.

Bureaucrats may be increasingly chosen for their technical ability and trained in the affairs of their own ministry, but politicians (including ministers) do not necessarily share these skills. This dynamic occurs in all representative democracies but is exacerbated in the Pacific where Westminster institutions in particular have been characterised by high levels of incumbent turnover - as much as 50 percent at each election in some places - and regular ministerial reshuffles (Larmour 2005, Fraenkel 2009). Against this backdrop, the effectiveness of ministers from SIS is curtailed by their inability to attend successive IO meetings, while the imperatives of the numbers game mean that often the least qualified members of parliament receive portfolios while those with relevant expertise (former health professionals or school administrators for example) sit on the backbench. Organisations like the AusAID-funded Centre for Democratic Institutions, who provide training for Pacific parliamentarians, tend to focus on tackling what they perceive to be the root cause (instability), via courses on political party strengthening for example, rather than the outcomes.

More successful bureaucrats may move to growing numbers of regional and international organisations (Baker 1992, Liki 2001), which may not necessarily represent the interests of 
particular SIS. Even aid agencies, including international NGOs, provide many good jobs and create 'perverse incentives' that 'result in a flow of administrative and technical talent from the public sector' (Moore 2011: 1771). Such individuals remain in the region but are no longer specifically involved in national development. (A parallel loss can be that of skilled workers employed by transnational corporations or tax havens, whose interests likewise are not always those of island states). Ironically such workers are highly visible locally and provide a model of successful mobility.

Limited economic growth and development opportunities have resulted in substantial out migration, including of highly skilled workers, notably in the health sector (Connell 2009b), reducing the pool of qualified professionals. Poor career prospects and low pay, limited recognition, frequent reshuffles, and lack of clear policy direction discourage public sector employment, and deaden enthusiasm. Some of the kinds of people with ambition and education, who might be expected to offer leadership and management expertise, have left, permanently or temporarily. Such trends have been apparent for several decades in contexts where 'only a few brains need to be drained before a serious systemic crisis occurs' (Baker 1992: 16). In very small states where recruitment to the public service may be linked to nepotism and patronage the skill base may be reduced further.

International forums are increasingly highly technical arenas and both political leaders and public service delegates rely heavily on the advice of officials for analytical support. However, while complex international negotiations require complex technical knowledge, skilled human resources are scarce, and recruitment, development and retention of high quality officials are perpetual challenges. As a Tongan Minister said in a more general context: at international 
meetings 'you feel intimidated because you don't have the capacity to engage', a sentiment echoed by this ni-Vanuatu politician:

It's a big issue for the WTO. The US has got armies based in Geneva and we have got one person. It's the same thing with these trade agreements; we can't even negotiate for ourselves and the people who are going are compromised by the whole gravy train thing. It's hard to deal with if you haven't got the people and resources. Where negotiating skills are as important as technical knowledge, in trade or aid deliberations, SIS are further disadvantaged by experience and language (Jones, Deere-Birkbeck \& Woods 2010: xi-xii). Interpretive knowledge is also invaluable in a context of multiple technical documents and consultancy reports, whose conclusions and recommendations may differ considerably. Advice and documents appropriate to the needs of large states may both overwhelm smaller states, by their number and complexity, and even disrupt planning, when, for example, SIS are part of regional organisations based in Asia, or even global organisations such as the Commonwealth Secretariat, that produce unsolicited reports more appropriate to the needs of very different economies and cultures. Without the international or domestic ability to critically access external 'advice', and without the development plans that accompanied the early decades of independence in SIS, the choice and implementation of development strategies are rarely easy.

Somewhat differently, senior positions may not be filled because of a lack of qualified personnel. A recent analysis of Kiribati found nine long-term unfilled director-level financial management positions in the Audit Office and Ministry of Finance since no appropriately skilled people were available, while 'staff are constantly overloaded and frequently drawn away from core tasks by 
workshops, consultations, and training sessions. Those acquiring formal qualifications or marketable skills tend to seek employment in better-remunerated roles with donor agencies or overseas. The consequence is a perpetual shortage of both people and skills' (Haque et al 2012: 16-17; see also Negin et al 2012). Turnover within particular departments and ministries, and thus in relationships with IOs, is a further complicating problem, while even more rapid turnover characterises political representatives.

Bureaucrats drafted into such meetings at short notice have little ability to participate effectively. As a Nauruan minister put it:

It is always more difficult for a small island state to participate $\ldots$ because even the lead up would require a lot of people to be dedicated to just looking at the material and the reports coming in from consultants in a very tight timeframe in order to make a recommendation to cabinet to develop a national position. Developed countries can do that, they have the resources, the people and the experts who are constantly looking at the figures and whatever needs to be looked at but we just don't have that. The bigger the meeting the more difficult it is to participate...We are just outgunned by all of the other countries that are there. They are better equipped.

Many meetings effectively demand some national input, such as a country paper that may require sophisticated analysis and drafting, or have parallel sessions, that spread human resources even more thinly.

Pressures on bureaucracies have increased as SIS expansion has been constrained both by domestic financial resources and by pressure from international organisations, such as the ADB, to reduce the size of the public service and privatise some government functions (Mok and Yep 
2008). At the same time, in most SIS the number of statutory organisations has grown, in areas such as national parks or coastal management, placing additional technical, legal and economic demands on government; there is a limited skills base for developing appropriate regulatory procedures and law enforcement. Inadequate numbers of skilled health workers, especially at management level, have reduced the effectiveness of health care delivery in Pacific SIS, in the organized provision of infrastructure, goods and technology, the inadequate delivery of services, in areas such as geriatrics and mental care, and in worsened morale and high attrition rates (Connell 2009b). Further, external pressures, mainly from aid donors, to incorporate particular themes in development planning (which have added such dimensions as gender, social inclusion, environment and climate change) have further increased the complexity and work involved, often requiring bureaucrats to engage in additional training. The WTO, for example, provide some training support for members - including web-based induction modules - and have established a Work Programme on Small Economies (Wallis 2010: 264).

While it is difficult to assess bureaucratic performance, or the extent to which this is reduced by external (and other) pressures, the ability to manage public expenditure and financial accountability is also limited. 'Facing sustained and severe shortages of trained staff small countries struggle to successfully complete all of the processes. While smallness exerts an overall negative impact [it] is felt most strongly in areas where highly specialised capacities are required' (Haque et al 2012: 3). Similarly absorptive capacity, in terms of overseas aid management, is weak and may be becoming weaker. Despite commitments to harmonisation, notably the 2005 Paris Declaration on Aid Effectiveness, the proliferation of aid donors and projects has sapped the attention, energy and resources of recipient governments, and reduced the capacity for aid management, policy development and practical implementation (somewhat 
ironically, the solution to this problem has been an increased focus on 'good governance'). When combined with endogenous human resource constraints, the cumulative effect on SIS is a lack of 'competitiveness' in IOs.

Governance is further challenged in contexts where national data on which to make decisions are often inadequate (e.g. on the extent and distribution of poverty) and those involved in decisionmaking may not always want data to be available. Research capacity is limited. Personalities and private interests are more likely to be involved and to overlap. National agencies (ministries and statutory organisations etc.) deal with a host of regional and global IOs, but also with academic researchers, consultants and private sector representatives, adding to bureaucratic congestion and overload. Bureaucrats now 'lament being constantly invited to meetings, with some citing several invitations in the same week by the same agency.' As one official put it, there is 'growing uneasiness, a sense that things are getting out of control', particularly as it relates to high transaction costs and duplication (Nielsen 2012: 2).

Limited bureaucratic capacity substantially impacts all areas of public policy-making in most SIS. However, these limitations are most acutely felt in the arena of international affairs. The costs of maintaining diplomatic representation overseas are considerable and Pacific SIS are usually represented in only a few destinations - generally some combination of New York, Washington, Geneva, Canberra, Auckland and Suva. These include some of the most expensive cities in the world. Some SIS have also sought to establish tourism and trade offices overseas. However, small states 'generally lack the financial and human resources to properly staff and fund the required embassies and missions' (Laurent 2011: 219), so affecting their ability to be aware of international trends and negotiate. To overcome this, Australia provided shared office 
space so that the smallest Commonwealth states could sustain a permanent mission in New York; only Kiribati does not to have a permanent mission there. However, while embassies may be subsidised by donors, real estate, rentals and residences, and the accoutrements (cars etc.) can be extremely expensive. To negate problems associated with both costs and limited technical expertise, SIS are often represented by roving ambassadors in international forums and rely heavily on the advice of consultants on specific issues.

In the UN SIS often experience difficulty in voicing their concerns, partly because they have so few representatives (averaging 2.5 per mission, compared with 21 for Western European and 8 for African missions) to enable constant vigilance, or give adequate focus to particular issues, even within blocs. Ambassadors themselves believed their perceived inability to influence opinion was a function of both inadequate technical expertise, and of the Pacific being seen as idyllic, peripheral or doomed to disappear, and in each case unlikely to attract resources or concerned attention (McNamara 2009). Even in vital discussions over climate change, Pacific island SIS 'struggle in terms of the number of people representing them at the climate change negotiations', averaging 5.8 delegates per country at the Kyoto conference compared with an average of 21 (Barnett and Campbell 2010: 93-4). Consequently small states usually exhibit limited effective participation in world affairs, and, echoing Keohane (1969), rely on larger states, usually former colonial powers, for some degree of protection and partnerships. However, such metropolitan states do not necessarily share common objectives. As one Samoan minister has outlined:

UN stuff, deadly. I got onto the UNESCO Executive Board. After making that whole effort I got there and I thought "I think I have made a mistake" ... it was about 
[getting] Pacific representation at that level ... But UN Agencies, they are a varied lot ... talking about people having perceptions of politicians being corrupt, there is this whole thing about $\mathrm{UN}$ officials ... I mean there are horror stories. ... we didn't have a permanent representation and so I made a point of building a network, one with small states and two particularly with people who have permanent representation in Paris, because then you get all the dirt ... who is getting the money ... I tell you, I reckon that [international politics] is the meanest level of politics, you really get to see the ugly side. There is no finesse. It's like "okay if you want this then you will have to do that". So you are getting all of the different blocs moving around doing this, and I'm thinking "how do you run consensus?" ... I am full of admiration for people who move onto that next level ... I'm sure some good works must have been done ...

The tendency for major IO meetings to be held in Europe or America places a significant additional burden on leaders from Pacific SIS who may travel for days on irregular transport links to take their seat on the world stage, a gruelling picture sketched by a Solomon Islands minister: 'When I was Foreign Minister I was very busy ... I travelled a lot during my time ... For example, we amended the Lomé Convention, the fourth protocol, it took us almost a year to discuss it at the EU level'. Implicit is the disorientation and disruption that travel imposes and the inability to simultaneously engage in national development and governance.

Despite the disadvantages, this kind of negative perception is not universal. Leaders often recalled the satisfaction that came from being one of the more-or-less equal voices of sovereign states in international forums and related how they appreciated being afforded the same courtesies as representatives from larger countries. As one Samoan minister articulated: 
I enjoyed the overseas trips and the networking. I think it was good meeting your other colleagues, not only in the region. I think with the Environment [Ministry] you met a lot of people in Europe, most of the meetings were in Geneva or Bonn or somewhere. Long, long trips but they were fairly advanced and that's where the money is in terms of big organisations.

Others reflected on the exposure and education, that they would not otherwise have had access to, obtained through IO work:

I enjoyed travelling, because it exposes you. Don't forget my background: a limited education. So, in going abroad one broadens one's horizons ... I loved listening to discussions that pertain to international matters... I enjoyed mingling with people at that level of interaction (Solomon Islands minister).

This intrinsic satisfaction does not counter the endemic limitations presented by the relative scarcity of skilled negotiators and the opportunity costs of taking them from other important activities. Indeed it may be that the most significant word in this statement is 'listening'; being heard, influencing and changing are rather more difficult.

This has not always been the case. In immediate post-colonial times, certain leaders, in specific circumstances, such as the inaugural Prime Minister of Fiji, Ratu Sir Kamisese Mara, were able to significantly influence the international system, in an era of beneficence from established states to new nations. In many respects this exception proves the general rule, as the unique circumstances of his prime ministership, centred on his own personal skills, knowledge and authority, good advice, a less complicated international environment and post-colonial good will, were briefly able to overcome the more general context of human resource constraints, even in 
one of the largest and most developed countries in the region ([omitted]). The post-independence years, however, are long gone, replaced by a complex global governance regime. It is no longer possible for this kind of unusually centralised and authoritarian leadership to exist without particular checks and balances, and without the bureaucratic congestion that was then beginning to occur. Certainly, contemporary leaders in Pacific SIS, especially in Melanesia but also Nauru and Tuvalu, for example, where the imperatives of coalition government encourage the proliferation of ministerial portfolios and the decentralisation of power, rarely enjoy such secure tenure, yet the requirements of leadership and governance have grown as the longevity of leaders has fallen.

\section{Overcoming the Disadvantages of Size in IOs}

Several solutions have been proposed by both the international community and island leaders to overcome the endogenous limitations of smallness, including the WTO internship program and the Commonwealth Secretariat's Small States Office. Improved governance is widely regarded as a solution to the problem of bureaucratic capacity. Demands for 'good governance' have constituted a form of regulatory regionalism through 'capacity building' (Hameiri 2009, Harris and Goldsmith 2012), effectively a transition from the role of aid in economic and social development to the prevention of state fragility and failure, and enhancement of regional security. Such external emphasis on inadequate governance and capacity, let alone on 'failed states', has seen a transition from descriptors to prescriptive ethical categories (Mitchell 2010) that have defined the innate identities of Pacific island societies, justified external interventions and reinforced "their feeling of "smallness" and insignificance in a global community' (Ratuva 2004: 87-88). Remarkably little analysis however has traced the relationship between aid delivery and development in SIS, although it is probably most effective where good local policy 
contexts exist and where aid responds to local needs, which, as in Samoa, has been a function of high-level leadership in aid coordination, the ability to reject approaches that did not fit in with national priorities, and the capacity and stability of key staff (Delay 2005).

Similarly, enhanced regionalism is also often touted as a panacea to the economies of scale that Pacific Island bureaucracies suffer from (see [omitted]). Pooling resources should allow SIS to overcome problems associated with economies of scale and relative isolation. However, while regional organisations have proliferated and expanded, this has not alleviated the pressures on limited numbers of skilled professionals (if anything the propensity for regional organisations to poach the best talent has exacerbated national problems); bureaucrats lament the proliferation of meetings, especially with regional agencies, that add to workloads, have unhelpfully mixed mandates, little continuity of staff attendance, duplicate activities and distract them from work (Negin et al 2012). From this perspective administrative capacity is seen as a collective action problem, but this largely ignores the extent to which Pacific Island countries are often competitors, rather than natural allies, at a regional level.

For various reasons, neither of these possible solutions receives widespread support amongst leaders who may rhetorically endorse both but privately concede they ignore domestic political imperatives. Instead, small states tend to turn to expatriate expertise for advice and representation; this is, in many ways, the obvious solution to a Weberian capacity problem. However, while experienced and effective civil servants can ameliorate these challenges, expatriates have not necessarily been dedicated to national objectives and have made commitments on behalf of SIS that should have been discouraged had national officials had 
greater knowledge and awareness (Grynberg 2010; Wallis 2010). More generally, as a Nauruan politician has said:

They didn't grow up as a Nauruan. They don't know how much I value the reef for instance. They don’t know my values. They don’t necessarily, when they provide advice, carry those values into that advice.

Beyond such values, regional and global asymmetries prevail. As has been politely phrased for trade negotiations, 'the research and information provided by external consultants are not always tailored to the needs of small states, and there are concerns that some information is biased towards the interests of donors' (Jones, Deere-Birkbeck and Woods 2010: xiii). Consequently 'The inability of the administration to be selective in its choice of visiting advisers and their terms of reference was equalled by its inability to evaluate or even process the often conflicting reports which they left behind them' (Jacobs 1975: 140). What was true thirty-eight years ago is probably truer now with the proliferation of international agencies. More frequently, good (and bad) advice simply does not reach the right place, is ignored, overlooked or forgotten. Indeed the Pacific Islands Forum has noted a 'mission overload' as 'plane loads of consultants arrive every week to plunder Pacific expertise for reports that often get left on the shelf' and consequently concluded that 'development partners need to reduce the number of missions, provide forward mission schedules and adhere to governments' mission-free periods' (quoted in McLellan 2013: 360).

Finally, leaders of SIS have also sought to manage and counteract asymmetry in these settings through better targeting their limited resources towards the most important policy issues. But, even when concentrating on one specific issue, effectiveness is constrained: 
We don't have the same resources either monetary or human. We might not have a team of 20 experts but we might get a quality two or three experts to assist us. That costs money but you also try and focus on specific issues that are relevant where you are not trying to do the whole package (former Nauru President).

However limited and formally unproductive attendance at global meetings might be they nonetheless provide an opportunity for networking, as the previous quote by the Samoan representative on the UNESCO board and the following illustrate:

Sometimes you attend a meeting without a planned intervention but you are there to create networks and hoping to meet different states and different donor agencies and establish a network that will be important to you. But most times a lot of the meetings are just talkfests (Nauruan Minister)

Networking and the ability to deal directly with possible aid donors provide some justification for attending meetings that might otherwise be inaccessible 'talkfests', as this Tuvaluan minister's reflection on the strategic possibilities of attendance illustrates:

We have a travel allowance to attend the international meetings. From there we can ask for money, if they can assist us. Mostly the donors work together with the staff concerned.

In contrast, one response to the demands of IOs has been for some SIS to curtail their commitments to some organisations and reduce the number of meetings attended. In 2006 then Prime Minister of Tuvalu, Apisai Ielemia banned overseas travel for all civil servants, including cabinet ministers, unless they were funded by donors (Pareti, 2006). Others, like this Marshallese minister, claim to have voluntarily adopted this type of approach for similar reasons: 
I was the Minister that travelled the very, very least. If I wanted to travel, I made a policy for myself. I would travel if I was funded by outside sponsors. I would [also] travel for Government if it is really necessary ... Other than that I wouldn't travel. However, most believe that they do not have this luxury, as one former President of Nauru has said:

We are a country that is small, our economy is not that big, but we are putting a lot of resources into our office at the United Nations and we are making a lot of noise...

Currently we are chairing AOSIS on climate change issues...It's a fight you have to take up. If you don't take it up you miss the bus... Science tells you that it is probably the biggest challenge that we in the Pacific will be facing.

Developing such a focus without neglecting other functions of government is necessarily difficult.

\section{Conclusion}

The benefits of global governance for SIS have largely been overstated. Increased participation in IOs can be both a burden and a blessing; it can raise the profile of SIS (as in AOSIS or the ACP Group), enable networking and rally support for their causes, but the ability of leaders to steer policy directions is limited by capacity constraints, with SIS often unable to maximise opportunities in the international arena. While SIS can 'manoeuvre at the margins' (Jones, Deere-Birkbeck \& Woods 2010), and focus on particular arenas, such as climate change, the greater number and openness of IOs and trade structures have often eroded previous political influences, that were a legacy of the colonial era. The Commonwealth Secretariat has, more than most, sought ways to overcome this - the majority of its members are SIS - and yet, 
symptomatic of changing political influence, it faces its own challenges to retain relevance. Perversely, as Baldacchino (2010) has shown, some small polities have been remarkably adroit in manipulating international relationships and legal regimes to their advantage. However most were sub-national jurisdictions which are not required to maintain the complex bureaucratic apparatus of sovereign states that are members of IOs.

Almost forty years ago, on the eve of independence of most Pacific island states, Jacobs (1975) advised governments of small states to become better informed and tougher, but not only did he provide no indication of how that might be achieved, largely small states have been unable to act on that recommendation. Opportunities are theoretical rather than real. Whilst human resources have been boosted since independence, a deficit of human skills has been accentuated by the selectivity of international migration, and a distinct brain drain in some important national development sectors including finance, education and health. In terms of such basic but essential functions as the management of public expenditure, Haque et al (2012: 3) concluded that SIS needed to consider 'outsourcing various technical and highly-specialised roles on an ongoing basis, given the low likelihood that such capacities can be sustainably sourced from local labour markets': a stark contrast to the rhetoric of localisation and indigenisation that was paramount only decades ago.

While IOs are aware of endogenous limitations, and despite some important examples to the contrary, such as the profile achieved by the President of Kiribati, Anote Tong, in global climate talks, on the world stage SIS tend to perform the part they are given. Even without pressures to participate in IOs and in the particular forms of, for example, trade where asymmetry is inherent ([omitted]), SIS experience constraints within national bureaucracies and political systems, let 
alone within IOs (at both global and regional scale) and diplomacy, simply because of shortages of effective personnel (and the resources to train and remunerate them). Shortages are both domestic and international, thus SIS are forced to depend on external expertise, which may be costly and unsuitable.

Aside from the challenge such constraints present to those who see global governance as being an overwhelmingly positive move for SIS, in relationships with IOs sovereignty does not always equal control. What might superficially appear to be equal access is constrained by the availability of technical expertise to the detriment of the SIS involved. Membership of regional organisations is believed to compensate for this inherent disadvantage but they too are similarly constrained by limited human resources, have only weak international influence and are increasingly fragmented. Consequently asymmetries of size and power are compounded by the relative absence of bureaucratic capacity that membership of IOs has not been resolved. 


\section{References}

Amoamo, M (2013) Empire and Erasure: A Case Study of Pitcairn Island, Island Studies Journal, 8(2): 233-254.

Asian Development Bank (1995) Human Resource Development. Smaller Pacific Island Countries, Manila: ADB.

Australian Broadcasting Corporation (15 November 2013) 'Mystery Surrounds Tongan decision to join atomic energy agency':

http://www.radioaustralia.net.au/international/radio/program/pacific-beat/mystery-surroundstongan-decision-to-join-atomic-energy-agency/1220688 (accessed 24/12/2013)

Baker, R (1992) Scale and Administrative Performance: The Governance of Small States and Microstates, in R.Baker, ed, Public Administration in Small and Island States, West Hartford: Kumarian Press, 5-25.

Baldacchino, G. (2010). Island enclaves, Montreal and Kingston: McGill-Queen's Press.

Benedict, B (1967) Problems of Smaller Territories, London: Athlone Press.

Bray, M (1992) Educational planning in small countries, Paris: UNESCO.

Campling, L \& Rosalie, M (2006), 'Sustaining Social Development in a Small Island Developing State? The Case of Seychelles', Sustainable Development, 14(2): 115-25.

Carlsson, I, Ramphal, S, Alatas, A and Dahlgren, H (1995), Our global neighbourhood: The report of the commission on global governance, Oxford: Oxford University Press

Connell, J (2009a) 'We are not ready': colonialism or autonomy in Tokelau, in G. Baldacchino, ed, The Case for Non-Sovereignty, Abingdon: Routledge, 157-169.

Connell, J (2009b) The Global Healthcare Chain. From the Pacific to the World, New York: Routledge.

Connell, J (2013) Islands at Risk, Cheltenham: Edward Elgar.

Crocombe, R (2008), The South Pacific, (7th ed), Suva: Institute of Pacific Studies.

Crowards, T (2002), Defining the Category of 'Small' States', Journal of International Development, 14 (2): 143-79.

Delay, S (2005) Why Does Aid Management in Samoa Succeed?, Public Administration and Development, 25(5): 433-435. 
Dommen, E and Hein, P (eds) (1985), States, Microstates and Islands, Beckanham: Croom Helm.

Farrugia, C (1993) The Special Working Environment of Senior Administrators in Small States, World Development, 21(2): 221-226.

Fraenkel, J. (2009) Oceania's Political Institutions and Transitions, in S Levine. (ed) Pacific Ways: Government and Politics in the Pacific Islands, Wellington: Victoria University Press, 277-302.

Gay, D (2005), 'Vanuatu's Suspended Accession Bid: Second Thoughts?', in P Gallagher, P Low and A Stoler (eds), Managing the Challenges of WTO Participation, Cambridge: Cambridge University Press, 590-606.

Gibson, J (2007) Is remoteness a cause of slow growth in the Pacific? A spatial-econometric analysis, Pacific Economic Bulletin, 22 (1): 83-101.

Grynberg, R and Joy, R (2006) 'The accession of Vanuatu to the WTO: lessons for the multilateral trading system', in R Grynberg (ed.) WTO at the Margins, Cambridge: Cambridge University Press, pp. 693-714.

Hameiri, S (2009) The region within: RAMSI, the Pacific Plan and new modes of governance in the Southwest Pacific, Australian Journal of International Affairs, 63(3): 348-360.

Haque, T, Knight,D and Jayasuriya, D (2012) Capacity Constraints and Public Financial Management in Small Pacific Island Countries, World Bank Policy Research Working Paper No. 6297, Washington.

Harris, V and Goldsmith, A (2012) Police in the Development Space: Australia's international police capacity builders, Third World Quarterly, 33(6): 1019-1036.

Jacobs, B. (1975) Administrative Problems of Small Countries, in P. Selwyn, ed, Development Policy in Small Countries, London: Croom Helm, 134-143.

Jones, E, Deere-Birkbeck, C \& Woods, N (2010), Manoeuvring at the Margins. Constraints Faced by Small States in International Trade Negotiations, Commonwealth Secretariat, London.

Keohane, R. (1969). Lilliputians' Dilemmas: Small States in International Politics. International Organization, 23 (2): 291-310.

Larmour, P. (2005) Foreign flowers: institutional transfer and good governance in the Pacific Islands. Honolulu: University of Hawai'i Press. 
Laurent, E (2011) 'Priorities for small states in global trade governance', in C Deere Birkbeck (ed.) Making Global Trade Governance Work for Development, Cambridge: Cambridge University Press, 204-30.

Liki, A (2001) Moving and rootedness: The paradox of the brain drain among Samoan professionals, Asia-Pacific Population Journal, 16(1): 67-84.

McIntyre, W (2012) The partition of the Gilbert and Ellice Islands, Island Studies Journal, 7(1): 135-146.

Maclellan, N (2013) The Region in Review: International Issues and Events, 2012, The Contemporary Pacific, 25(2): 352-368.

MacQueen, N (1993) Island South Pacific in a Changing World, The Pacific Review, 6(2): 145153.

Malielegaoi, S. (2005) Address by the Hon. Prime Minister of Samoa on the future of regionalism in the Pacific. Pacific Cooperation Foundation Annual Pacific Lecture. Wellington, 22 March, 2005.

McNamara, K (2009) 'Voices from the margins: Pacific ambassadors and the geopolitics of marginality at the United Nations', Asia Pacific Viewpoint, 50(1): 1-12.

Mitchell, K (2010) Ungoverned space: Global security and the geopolitics of broken windows, Political Geography 29(5):289-297.

Moisio, S (2011) Political geographies of the state and scale, Political Geography 30(3):173174.

Mok, Ka Ho and R.Yep (2008) Globalization and state capacity in Asia, The Pacific Review 21(2):109-120.

Moore, M (2011) Globalisation and Power in Weak States, Third World Quarterly, 32(10): 1757-1776.

Murray, D (1985) Public Administration in the Microstates of the Pacific, in E. Dommen and P. Hein, (eds), States, Microstates and Islands, Beckenham: Croom Helm, 185-203.

Negin, J, Morgan, C \& Condon, R (2012), Regional Health Meetings in the Pacific and their Impact on Health Governance, Global Health Governance 5(2): 1.

Nielsen, J (2012) So many meetings, so little impact, Development Policy Blog, Australian National University: http://devpolicy.org/so-many-meetings-so-little-impact20120723/ (accessed 10.10.2013) 
Norris, P. 2012. Making Democratic Governance Work: How Regimes Shape Prosperity, Welfare, and Peace. Cambridge: Cambridge University Press.

Pace, R (2006) Malta and EU Membership: Overcoming 'Vulnerabilities', Strengthening 'Resilience', European Integration 28(1):33-49.

Pareti, S (2006) Overseas Trip Ban for Tuvalu, Islands Business, 32 (10), October, 30.

Rapaport, J, Muteba, E and Therattil, J (1971) Small States and Territories: Status and Problems, New York: Arno Press.

Rothstein, R. (1966) Alignment, Nonalignment, and Small Powers: 1945-1965, International Organization, 20(3): 397-418.

Ratuva, S (2004) The dilemma of smallness: globalization and challenges for Pacific governance and foreign policy, in N. Sullivan ed, Governance Challenges for PNG and the Pacific Islands, Divine Word University Press, Madang, 87-92.

Schahczenski, J (1992) Development Administration in the Small Developing State: A Review, in R.Baker, (ed), Public Administration in Small and Island States, West Hartford: Kumarian Press, 34-48.

Stringer, K. D. (2006). Pacific island microstates: pawns or players in Pacific rim diplomacy? Diplomacy and Statecraft, 17(3): 547-577.

United Nations Commisson on Global Governance (1995) Our Global Neighbourhood, Oxford and New York: Oxford University Press

Van Fossen, A. (2007). The struggle for recognition: diplomatic competition between China and Taiwan in Oceania. Journal of Chinese Political Science, 12(2): 125-146.

Veenendaal, W. P. (2013a) Politics and democracy in microstates, Institute of Political Science, Faculty of Social and Behavioural Sciences, Leiden University.

Vital, D. (1971) The survival of small states: studies in small power/great power conflict, London: Oxford University Press.

Wallis, J (2010) 'Friendly islands' in an unfriendly system, Asia Pacific Viewpoint, 51 (3): 26277.

Warrington, E. (1998) Gulliver and Lilliput in a new world order: the impact of external relations on the domestic policies and institutions of micro-states, Public Administration and Development 18(2):101-105. 
Wettenhall, R (2001) Machinery of government in small states: issues, challenges and innovatory capacity, Public Organization Review 1(2):167-192.

Wivel, A and K. Oest (2010) Security, profit or shadow of the past? Explaining the security strategies of microstates, Cambridge Review of International Affairs 23(3):429-453.

World Bank (2012) Statistics for Small States 2011, Washington DC: World Bank.

Xu, Y. \& Weller, P. (2009). Inside the World Bank: Exploding the Myth of the Monolithic Bank. New York: Palgrave MacMillan.

Yanow, D., \& Schwartz-Shea, P. (2010). Interpretive Research: Characteristics and Criteria. Revue internationale de Psychosociologie, 15(35): 29-38. 
Table 1: Political Entities in the Pacific Islands

\begin{tabular}{lll}
\hline Country & $\begin{array}{l}\text { Land Area } \\
\text { (km2) }\end{array}$ & $\begin{array}{l}\text { Population } \\
\text { (2011 estimates) }\end{array}$ \\
\hline \hline Cook Islands & 240 & 15,500 \\
FSM & 701 & 102,000 \\
Fiji & 18,300 & 852,000 \\
Kiribati & 810 & 95,000 \\
Marshall Islands & 181 & 55,000 \\
Nauru & 21 & 10,000 \\
Niue & 259 & 1,400 \\
Palau & 490 & 21,000 \\
Samoa & 2,934 & 184,000 \\
Solomon Islands & 28,370 & 553,000 \\
Tonga & 650 & 104,000 \\
Tuvalu & 26 & 11,000 \\
Vanuatu & 12,190 & 252,000 \\
\hline
\end{tabular}


Table 2: IO Membership of Pacific Island States

\begin{tabular}{|c|c|}
\hline Country & IO Membership \\
\hline Cook Islands & $\begin{array}{l}\text { ACP, ADB, AOSIS, FAO, ICAO, ICRM, IFAD, IFRCS, IMO, IMSO, } \\
\text { IOC, ITUC (NGOs), OPCW, UNESCO, UPU, WHO, WMO }\end{array}$ \\
\hline FSM & $\begin{array}{l}\text { ACP, ADB, AOSIS, FAO, G-77, IBRD, ICAO, ICRM, IDA, IFC, } \\
\text { IFRCS, IMF, IOC, IOM, IPU, ITSO, ITU, MIGA, OPCW, UN, } \\
\text { UNCTAD, UNESCO, WHO, WMO }\end{array}$ \\
\hline Fiji & $\begin{array}{l}\text { ACP, ADB, AOSIS, C (suspended), CP, FAO, G-77, IAEA, IBRD, } \\
\text { ICAO, ICRM, IDA, IFAD, IFC, IFRCS, IHO, ILO, IMF, IMO, } \\
\text { Interpol, IOC, ISO, ITSO, ITU, ITUC (NGOs), MIGA, NAM, OPCW, } \\
\text { PCA, UN, UNCTAD, UNESCO, UNIDO, UNMISS, UNMIT, } \\
\text { UNWTO, UPU, WCO, WFTU (NGOs), WHO, WIPO, WMO, WTO }\end{array}$ \\
\hline Kiribati & $\begin{array}{l}\text { ACP, ADB, AOSIS, C, FAO, IBRD, ICAO, ICRM, IDA, IFAD, IFC, } \\
\text { IFRCS, ILO, IMF, IMO, IOC, ITU, ITUC (NGOs), OPCW, UN, } \\
\text { UNCTAD, UNESCO, UPU, WHO, WMO }\end{array}$ \\
\hline Marshall Islands & $\begin{array}{l}\text { ACP, ADB, AOSIS, FAO, G-77, IAEA, IBRD, ICAO, IDA, IFAD, } \\
\text { IFC, ILO, IMF, IMO, IMSO, Interpol, IOC, ITU, OPCW, UN, } \\
\text { UNCTAD, UNESCO, WHO }\end{array}$ \\
\hline Nauru & $\begin{array}{l}\text { ACP, ADB, AOSIS, C, FAO, G-77, ICAO, Interpol, IOC, IOM, ITU, } \\
\text { OPCW, UN, UNCTAD, UNESCO, UPU, WHO }\end{array}$ \\
\hline Niue & ACP, AOSIS, FAO, IFAD, OPCW, UNESCO, UPU, WHO, WMO \\
\hline Palau & $\begin{array}{l}\text { ACP, ADB, AOSIS, FAO, IAEA, IBRD, ICAO, ICRM, IDA, IFC, } \\
\text { IFRCS, ILO, IMF, IMO, IMSO, IOC, IPU, MIGA, OPCW, UN, } \\
\text { UNAMID, UNCTAD, UNESCO, WHO }\end{array}$ \\
\hline Samoa & $\begin{array}{l}\text { ACP, ADB, AOSIS, C, FAO, G-77, IBRD, ICAO, ICRM, IDA, IFAD, } \\
\text { IFC, IFRCS, ILO, IMF, IMO, Interpol, IOC, IPU, ITU, ITUC (NGOs), } \\
\text { MIGA, OPCW, UN, UNCTAD, UNESCO, UNIDO, UPU, WCO, } \\
\text { WHO, WIPO, WMO, WTO }\end{array}$ \\
\hline Solomon Islands & $\begin{array}{l}\text { ACP, ADB, AOSIS, C, EITI (candidate country), ESCAP, FAO, G-77, } \\
\text { IBRD, ICAO, ICRM, IDA, IFAD, IFC, IFRCS, ILO, IMF, IMO, IOC, } \\
\text { ITU, MIGA, OPCW, UN, UNCTAD, UNESCO, UPU, WFTU, WHO, } \\
\text { WMO, WTO }\end{array}$ \\
\hline Tonga & $\begin{array}{l}\text { ACP, ADB, AOSIS, C, FAO, G-77, IAEA, IBRD, ICAO, ICRM, IDA, } \\
\text { IFAD, IFC, IFRCS, IHO, IMF, IMO, IMSO, Interpol, IOC, ITU, } \\
\text { ITUC (NGOs), OPCW, UN, UNCTAD, UNESCO, UNIDO, UPU, } \\
\text { WCO, WHO, WIPO, WMO, WTO }\end{array}$ \\
\hline
\end{tabular}


Tuvalu

Vanuatu
ACP, ADB, AOSIS, C, FAO, IBRD, IDA, IFRCS (observer), ILO, IMF, IMO, IOC, ITU, OPCW, UN, UNCTAD, UNESCO, UNIDO, UPU, WHO

ACP, ADB, AOSIS, C, FAO, G-77, IBRD, ICAO, ICRM, IDA, IFC, IFRCS, ILO, IMF, IMO, IMSO, IOC, IOM, ITU, ITUC (NGOs), MIGA, NAM, OAS (observer), OIF, OPCW, UN, UNCTAD, UNESCO, UNIDO, UNWTO, UPU, WCO, WFTU (NGOs), WHO, WIPO, WMO, WTO

${ }^{\mathrm{i}}$ Retrieved from \https://www.cia.gov/library/publications/the-world-factbook/, 27/02/2013. 